Article

\title{
Risk Profile Indicators and Spanish Banks' Probability of Default from a Regulatory Approach
}

\author{
Pilar Gómez-Fernández-Aguado ${ }^{(D)}$, Purificación Parrado-Martínez ${ }^{\mathbb{D}}$ and \\ Antonio Partal-Ureña * (iD \\ Department of Financial Economics and Accounting, University of Jaén, 23071 Jaén, Spain; \\ pigomez@ujaen.es (P.G.-F.-A.); pparrado@ujaen.es (P.P.-M.) \\ * Correspondence: apartal@ujaen.es
}

Received: 25 February 2018; Accepted: 16 April 2018; Published: 19 April 2018

check for updates

\begin{abstract}
This paper analyses the relationships between the traditional bank risk profile indicators and a new measure of banks' probability of default that considers the Basel regulatory framework. First, based on the SYstemic Model of Bank Originated Losses (SYMBOL), we calculated the individual probabilities of default (PD) of a representative sample of Spanish credit institutions during the period of 2008-2016. Then, panel data regressions were estimated to explore the influence of the risk indicators on the PD. Our findings on the Spanish banking system could be important to regulatory and supervisory authorities. First, the PD based on the SYMBOL model could be used to analyse bank risk from a regulatory approach. Second, the results might be useful for designing new regulations focused on the key factors that affect the banks' probability of default. Third, our findings reveal that the emphasis on regulation and supervision should differ by type of entity.
\end{abstract}

Keywords: probability of default; bank risk; banking regulation; SYMBOL; financial stability

\section{Introduction}

The review of the international financial regulatory framework has set two objectives for financial stability: first, to reduce the probability of the bankruptcy of financial institutions by increasing solvency; and, second, to reduce public costs in the event of a bank crash and improve the framework for resolution. Regulatory reform in the European Union (EU) has been conducted by introducing the policies agreed upon by the G-20 using three directives that are the pillars of the banking union: (1) Directive IV (Directive 2013/36/EU of the European Parliament and of the Council of 26 June 2013 on access to the activity of credit institutions and the prudential supervision of credit institutions and investment firms, amending Directive 2002/87/EC and repealing Directives 2006/48/EC and 2006/49/EC) and Capital Requirements Regulation (CRD IV and CRR, 2013), which incorporates the third Basel agreement on micro-prudential regulation [1] (Basel III), significantly increasing the capital and liquidity requirements of financial institutions to manage unexpected losses; (2) the Directive on Banking Resolution and Recovery (Directive 2014/59/EU of the European Parliament and of the Council of 15 May 2014 establishing a framework for the recovery and resolution of credit institutions and investment firms), which establishes a set of rules and resolution tools, such as the sale of the company or shares of the entity subject to resolution, the creation of a bridge entity, the separation of productive assets from impaired assets or underperforming assets of an entity, and the rescue of shareholders and creditors in difficulty; and (3) a directive on deposit guarantee schemes (Directive 2014/49/EU of the European Parliament and of the Council of 16 April 2014 on deposit guarantee schemes) to preserve retail deposits at all times.

The importance of analysing the effects that regulatory standards have on financial stability requires the development of models and risk measures that can be adjusted to the actual regulatory 
framework and can provide a basis for stress tests or quantitative impact studies. The European Union has recently started to use the SYMBOL model to assess the effectiveness of bank regulation and to measure the quantitative impact of a series of legislative proposals promoted by the European Commission [2,3]. SYMBOL is a model of micro-simulation based on the Basel risk assessment framework that estimates the distribution of bank losses originating in the system beginning with the balance and regulatory capital of individual banks. The methodological basis of the model was developed by the Commission's Joint Research Centre (JRC), the Directorate General Internal Market and Services and banking regulation experts (the original methodology was developed by De Lisa et al. [4], but, in this paper, the abbreviation SYMBOL was not employed).

While the SYMBOL model has been used to quantify systemic losses, it also provides a proxy for a bank's default probability as a tail risk [5] that reflects bank capital strength and asset quality [4]. The probability of default of a bank is estimated as the probability that its obligor's loss exceeds actual capital, given by the sum of its minimum capital requirement plus the bank's excess capital. In the Basel framework, each bank must satisfy a capital requirement that provides a buffer against unexpected losses at a specific level of statistical confidence, set by regulators at $99.9 \%$ [6]. From the regulatory perspective, the probability that banks default can be seen as the probability that banks' losses fall in the tail of their loss distribution. This "tail risk" is equal to $0.1 \%$ whenever banks set their amount of capital at a level equal to their regulatory minimum or lower if they hold capital in excess of the regulatory minimum. This risk occurs with a low probability, but it generates serious losses that endanger financial stability.

However, the recent development of this model indicates that there is currently no empirical evidence relating to the measurement of the likelihood of default to the indicators traditionally used for bank risk assessment. Our work extends the previous research on the determinants of bank risk, analysing the relationships between the risk indicators proposed by the European Banking Authority (EBA) [7] and the individual default probabilities of Spanish credit institutions during the period of 2008-2016, based on a new measure supported by banking regulation. We aim to determine whether these two sets of measures provide the same information of whether they are supplementary for bank risk analysis. After the last restructuring of the Spanish banking system, the regulation and supervision of bank risk have become crucial. In this sense, the analysis of new proxies from a regulatory approach could be decisive to avoid the financial instability. Indeed, this instability is a key obstacle to long-term investments which are required to achieve the sustainability in the financial system.

Our study is structured as follows. Section 2 presents a review of the literature. Section 3 describes the data and methodology employed. Section 4 presents and discusses the results. Finally, Section 5 concludes the study.

\section{Related Literature}

The literature on measuring the credit risk of banks and calculating the probability of default (PD) has been a focus in the use of accounting and market information. Studies that have used accounting information have basically applied two proxies for bank risk: NPL ratio and Z-score. The NPL ratio (non-performing loans (impaired loans) to total gross loans) or changes in the ratio have been used as a measurement of the strength of a bank [8-15] since they reflect the quality of a loan portfolio. A higher value of this ratio indicates a greater probability that the bank will default. Similarly, the Z-score has been widely used to measure bank risk [16-20]. Z-scores equal the return on assets plus the capital-to-asset ratio divided by the standard deviation of asset returns. A higher Z-score indicates that a bank is farther from default [21].

At the same time, research using market information as a complement to accounting indicators has been based on Merton's [22] approach to modelling the risk of credit defaults. Some studies have used credit risk spread CDs [23-31] or credit ratings [32-34].

More recently, De Lisa et al. [4] introduced a methodology for the estimation of the probability of the default of a bank based on the framework of capital requirements for credit risk from the Basel 
agreements. Based on public balance sheet data and the regulatory capital of the entities, the probability of the default of a bank (PD Bank) is defined as the probability that unexpected losses associated with the portfolio's debtors (implied obligor probability of default, IOPD) exceed bank capital (given by the sum of regulatory capital requirements and any excess capital).

The methodology developed by De Lisa et al. [4] is the basis of the SYMBOL model. It has been used to evaluate the implications of new Basel III definitions (Risk weighted assets and computable resources), recent European banking regulation (CRD IV, CRR, Bank Recovery and Resolution Directive and Deposit Guarantee Schemes Directive), stress scenarios and quantitative valuations [2,3,35-39].

From a regulatory point of view, bank risk has traditionally been evaluated using indicators associated with different risk categories, such as capital adequacy, asset quality, liquidity and business model and management. EBA [7] proposed a series of indicators to determine bank risk profiles as the basis for contributions to deposit guarantee schemes. It also established the expected relationships (negative/positive) between indicators and bank risk.

This paper contributes to the existing literature by analysing the relationships between the traditionally used risk indicators and the new measure of a bank's PD based on the SYMBOL model.

\section{Data and Methodological Aspects}

\subsection{Sample}

Our sample consisted of Spanish credit institutions that have available information for all the analysed variables during the period of 2008-2016. Data were obtained from the banks' public documents (audited annual reports and information of prudential relevance). We used consolidated data since some risk indicators are not available on a solo basis. According to EBA (2015) guidelines, for each member institution, the values of risk indicators should be calculated on a solo basis. However, the value of risk indicators should be calculated at a consolidated level, at which the member state exercises the option given in Article 13(1) of DGSD to allow the central body and all credit institutions permanently affiliated with the central body, as referred to in Article 10(1) of Regulation (EU) 575/2013, to be subject as a whole to the risk weight determined for the central body and its affiliated institutions on a consolidated basis. Where a member institution has received a waiver from meeting capital and/or liquidity requirements on a solo basis pursuant to Articles 7, 8 or 21 of Regulation (EU) $575 / 2013$, the corresponding capital/liquidity indicators should be calculated at the consolidated or semi-consolidated level. The entities are classified into two groups: commercial banks and credit cooperatives. Savings banks are included in the first group because, after the restructuring process that occurred in the Spanish financial sector during the last financial crisis, the majority of these entities were transformed into commercial banks. There are notable differences between these two types of institutions regarding not only their objectives but also their sizes. The total assets of commercial banks are more than 30 times greater than the total assets of credit unions (Table 1).

After eliminating extreme values considered outliers, we finally had an unbalanced panel with 359 observations related to 70 entities during the period of 2008-2016. The panel represented $87.85 \%$ of the total assets in the Spanish banking system. Table 1 presents the number of observations that constitute the sample, organised by year and type of entity, as well as their representativeness.

Table 1. Number of observations and representativeness of the sample.

\begin{tabular}{lccccccccc}
\hline & $\mathbf{2 0 0 8}$ & $\mathbf{2 0 0 9}$ & $\mathbf{2 0 1 0}$ & $\mathbf{2 0 1 1}$ & $\mathbf{2 0 1 2}$ & $\mathbf{2 0 1 3}$ & $\mathbf{2 0 1 4}$ & $\mathbf{2 0 1 5}$ & $\mathbf{2 0 1 6}$ \\
\hline Number of commercial Banks & 43 & 46 & 30 & 30 & 18 & 20 & 19 & 20 & 20 \\
Number of cooperative credit unions & 11 & 12 & 12 & 14 & 13 & 13 & 11 & 14 & 13 \\
Total credit institutions & 54 & 58 & 42 & 44 & 31 & 33 & 30 & 34 & 33 \\
\hline
\end{tabular}


Table 1. Cont.

\begin{tabular}{lccccccccc}
\hline & $\mathbf{2 0 0 8}$ & $\mathbf{2 0 0 9}$ & $\mathbf{2 0 1 0}$ & $\mathbf{2 0 1 1}$ & $\mathbf{2 0 1 2}$ & $\mathbf{2 0 1 3}$ & $\mathbf{2 0 1 4}$ & $\mathbf{2 0 1 5}$ & $\mathbf{2 0 1 6}$ \\
\hline Total assets in commercial banks (billions of euros) & & & & & & & & \\
\hline Population & 3537.0 & 3637.6 & 3691.9 & 3793.9 & 3754.2 & 3358.6 & 3476.0 & 3555.5 & 3492.3 \\
Sample & 2848.8 & 3002.1 & 3304.5 & 3406.6 & 2850.9 & 3028.9 & 3174.8 & 3347.0 & 3305.1 \\
Representativeness of the sample (\%) & 80.5 & 82.5 & 89.5 & 89.8 & 75.9 & 90.2 & 91.3 & 94.1 & 94.6 \\
\hline Total assets in cooperative credit unions (billions of euros) & & & & & & \\
\hline Population & 71.4 & 77.5 & 91.5 & 107.0 & 113.1 & 114.3 & 103.1 & 110.4 & 110.5 \\
Sample & 69.3 & 75.8 & 86.9 & 100.9 & 106.7 & 108.5 & 99.3 & 110.4 & 108.5 \\
Representativeness of the sample (\%) & 97.1 & 97.9 & 95.0 & 94.3 & 94.4 & 94.9 & 96.4 & 100.0 & 98.2 \\
\hline Total assets in credit institutions (billions of euros) & & & & & & & \\
\hline Population & 3608.4 & 3715.1 & 3783.5 & 3901.0 & 3867.3 & 3472.9 & 3579.0 & 3665.9 & 3602.8 \\
Sample & 2918.1 & 3078.0 & 3391.5 & 3507.5 & 2957.7 & 3137.4 & 3274.1 & 3457.4 & 3413.6 \\
Representativeness of the sample (\%) & 80.9 & 82.9 & 89.6 & 89.9 & 76.5 & 90.3 & 91.5 & 94.3 & 94.8 \\
\hline
\end{tabular}

\subsection{Dependent Variable: Probability of Default (PD)}

SYMBOL simulates the distribution of losses in a banking system (usually a country) by aggregating individual banks' losses. Individual banks' losses are generated via Monte Carlo simulation using the Basel FIRB loss distribution function [40]. Simulated losses are based on an estimation of the average default probability of the portfolio of assets of any individual bank. Default of a bank is determined by the size of simulated losses and the regulatory capital available to absorb unexpected shocks. Banks are expected to cover their expected losses with provisions. Unexpected losses, in contrast, relate to potentially large losses that occur rather seldom. According to this concept, capital would be needed only for absorbing unexpected loss. The model thus assumes that [3]: (1) the Basel III regulatory model for credit risk is correct; (2) banks report risks accurately that are in agreement with this model; and (3) all risks in the bank can be represented as a single portfolio of credit risks (this representation does not indicate that other risks are not considered-simply that they can be "mapped" in credit risk terms and modelled using the same framework). The model is processed in four methodological steps $[4,38,41,42]$. The first, second and third stages are necessary to estimate the banks' individual probability of default (PD bank), and the last stage determines the aggregate loss distribution of the system as a whole. Below, we describe the methodological considerations to estimate a bank's PD.

\subsubsection{Estimation of the Implied Obligor Probability of Default of the Portfolio of Each Individual Bank}

The main parameter of the model is the average implied obligor probability of default of a bank $\left(I O P D_{i}\right)$. This variable is obtained from the Basel IRB formula to establish the minimum capital requirements for credit risk (FIRB approach). For each exposure $l$ of bank $i$, the IRB formula establishes capital requirement $\mathrm{CR}_{i, l}$ to cover the unexpected losses in the time horizon of one year for a $99.9 \%$ confidence level, as follows:

$$
\mathrm{CR}_{i, l}\left(\mathrm{PD}_{i, l}\right)=\left[\mathrm{LGD} \cdot \mathrm{N}\left(\sqrt{\frac{1}{1-\mathrm{R}\left(\mathrm{PD}_{i, l}\right)}} \cdot \mathrm{N}^{-1}\left(\mathrm{PD}_{i, l}\right)+\sqrt{\frac{\mathrm{R}\left(\mathrm{PD}_{i, l}\right)}{1-\mathrm{R}\left(\mathrm{PD}_{i, l}\right)}} \cdot \mathrm{N}^{-1}(0.999)\right)-\mathrm{PD}_{i, l} \cdot \mathrm{LGD}\right] \cdot \mathrm{M}\left(\mathrm{PD}_{i, l}\right)
$$

where $\mathrm{PD}_{i, l}$ is the default probability of exposure $l$; and $\mathrm{R}$ is the correlation among the exposures in the portfolio, defined as:

$$
R\left(\mathrm{PD}_{i, l}\right)=0.12 \cdot \frac{1-\mathrm{e}^{-50 \cdot \mathrm{PD}_{i, l}}}{1-\mathrm{e}^{-50}}+0.24 \cdot\left(1-\frac{1-\mathrm{e}^{-50 \cdot \mathrm{PD}_{i, l}}}{1-\mathrm{e}^{-50}}\right)-0.04 \cdot\left(1-\frac{s-5}{45}\right)
$$

where obligor size $s$ is equal to 50; LGD is the loss given default (considered to be $45 \%$ in the FIRB approach); and $\mathrm{M}\left(\mathrm{PD}_{i, l}\right)$ is an adjustment term, defined as: 


$$
\mathrm{M}\left(\mathrm{PD}_{i, l}\right)=\frac{\left(1+(M-2.5) \cdot b_{i, l}\right) \cdot 1.06}{1-1.5 \cdot b_{i, l}}
$$

where $M$ is the time to maturity (considered to be 2.5 years in the FIRB approach), and $b$ is the maturity adjustment, computed as $b_{i, l}=\left(0.11856-0.05478 \cdot \ln \left(\mathrm{PD}_{i, l}\right)\right)^{2}$.

The minimum capital requirement of the bank $\left(\mathrm{MCR}_{i}\right)$ is equal to the sum of the capital requirements of all the exposures:

$$
\mathrm{MCR}_{i}=\sum_{l} \mathrm{CR}_{i, l} \cdot \mathrm{A}_{i, l}
$$

where $\mathrm{A}_{i, l}$ is the amount of exposure $l$.

Because there is no available public information about the different banking exposures, the model considers only one debtor that is equivalent to the total portfolio, and it estimates $\operatorname{IOPD}_{i}$ by solving the following equation:

$$
\mathrm{CR}\left(\mathrm{IOPD}_{i}\right) \cdot \sum_{l} \mathrm{~A}_{i, l}=\mathrm{MCR}_{i}
$$

where $\mathrm{CR}\left(\mathrm{IOPD}_{i}\right)$ is the minimum capital requirement based on the Basel regulation (equal to $8 \%$ of the risk-weighted assets), and $\sum_{l} \mathrm{~A}_{i, l}$ is the total assets of the bank.

\subsubsection{Simulation of Correlated Losses for the Banks in the System}

Given the estimated IOPD, the SYMBOL model uses Monte Carlo simulation to generate the bank loss distribution, using the same IRB formula and imposing a correlation structure among banks (with a correlation coefficient set to $\rho=50 \%$ ). SYMBOL is often run imposing an equal correlation factor of $50 \%$ among all banks. A discussion and a sensitivity check of this assumption can be found in De Lisa et al. [4] and Benczur et al. [37]. This correlation exists as a consequence of the banks' common exposure, either to the same borrower or, more generally, to a particular common influence of the business cycle. In each simulation run $j$, losses for bank $i$ are simulated as:

$$
L_{i, j}=\mathrm{LGD} \cdot \mathrm{N}\left[\sqrt{\frac{1}{1-\mathrm{R}\left(\mathrm{IOPD}_{i}\right)}} \cdot \mathrm{N}^{-1}\left(\mathrm{IOPD}_{i}\right)+\sqrt{\frac{R\left(\mathrm{IOPD}_{i}\right)}{1-R\left(\mathrm{IOPD}_{i}\right)}} \cdot \mathrm{N}^{-1}\left(\alpha_{i, j}\right)\right]
$$

where $\mathrm{N}$ is the normal distribution function, and $\mathrm{N}^{-1}\left(\alpha_{n, i}\right)$ are correlated normal random shocks. $\mathrm{IOPD}_{i}$ is the implied obligor probability of default estimated for each bank in Step 1, and LGD is the loss given default, set as in the Basel regulation equal to $45 \%$.

\subsubsection{Determination of the Failure Event and Estimation of PD Bank}

In the SYMBOL model, a bank $i$ is considered in default when simulated losses $\left(L_{i j}\right)$ exceed the sum of the expected losses $\left(E L_{i}\right)$ and the total actual capital $\left(K_{i}\right)$ given by the sum of its minimum capital requirement plus the bank's excess capital:

$$
L_{i, j}-E L_{i}-K_{i}>0 \rightarrow \text { Bank } i \text { defaults }
$$

The probability of the default of a bank (PD bank) is calculated as the number of times that the bank defaults over the total number of simulations $(100,000)$.

\subsection{Independent Variables: Risk Profile Indicators}

As independent variables, we use the core risk indicators established by the EBA in 2015 [7] (Table 2). They include the following: (i) concerning capital, the leverage ratio (C1) and the capital coverage ratio, calculated as actual own funds divided by required own funds (C3) and the CET1 ratio (C4); (ii) concerning liquidity and funding, the LCR (L1), the NSFR (L2) and the liquidity ratio (L3); (iii) concerning asset quality, the non-performing loans (NPL) ratio (AQ1); and (iv) concerning business 
model and management, the risk-weighted asset to total assets ratio (G1) and the ROA (G2). Because we do not have information for some of the liquidity indicators proposed, we use the loans-to-deposits (LTD) ratio and the stable funding/stable assets (ST/SA) ratio as a proxy for the LCR and the NSFR, respectively. EBA [7] stated that competent authorities may exclude a core indicator upon justification that it is unavailable because of the legal characteristics or supervisory regimes of some institutions. In these cases, the most appropriate proxy should be used for the removed indicator.

Table 2. Core indicators of likelihood of failure.

\begin{tabular}{|c|c|c|c|c|}
\hline Category & Indicator & Description & Notation & $\begin{array}{l}\text { Expected Sign on } \\
\text { Bank Risk }\end{array}$ \\
\hline \multirow{3}{*}{ Capital } & Leverage ratio & Tier 1 capital/Total assets & $\mathrm{C} 1$ & Negative \\
\hline & Capital coverage ratio & $\begin{array}{l}\text { Actual common equity Tier } 1 \\
\text { ratio/Required common equity Tier } 1 \\
\text { ratio or actual own funds/Required } \\
\text { own fund }\end{array}$ & $\mathrm{C} 2 / \mathrm{C} 3$ & Negative \\
\hline & $\begin{array}{l}\text { Common equity Tier } 1 \\
\text { (CET1) ratio }\end{array}$ & $\begin{array}{l}\text { Common equity Tier } 1 \\
\text { capital/Risk-weighted assets }\end{array}$ & $\mathrm{C} 4$ & Negative \\
\hline \multirow{3}{*}{$\begin{array}{l}\text { Liquidity and } \\
\text { Funding }\end{array}$} & $\begin{array}{l}\text { Liquidity coverage ratio } \\
\text { (LCR) }\end{array}$ & $\begin{array}{l}\text { LCR ratio as defined in Regulation } \\
\text { (EU) No. } 575 / 2013 \text { once it becomes } \\
\text { fully operational }\end{array}$ & L1 & Negative \\
\hline & $\begin{array}{l}\text { Net stable funding ratio } \\
\text { (NSFR) }\end{array}$ & $\begin{array}{l}\text { NSFR ratio as defined in Regulation } \\
\text { (EU) No. } 575 / 2013 \text { once it becomes } \\
\text { fully operational }\end{array}$ & L2 & Negative \\
\hline & Liquidity ratio & Liquid assets/Total assets & L3 & Negative \\
\hline Asset Quality & $\begin{array}{l}\text { Non-performing loans } \\
\text { (NPL) ratio }\end{array}$ & $\begin{array}{l}\text { Non-performing loans/Total loans } \\
\text { and debt instruments }\end{array}$ & AQ1 & Positive \\
\hline \multirow[t]{2}{*}{$\begin{array}{l}\text { Business model } \\
\text { and management }\end{array}$} & $\begin{array}{l}\text { Risk-weighted assets to } \\
\text { total assets ratio } \\
\text { (RWA/TA) }\end{array}$ & Risk-weighted assets/Total assets & G1 & Positive \\
\hline & Return on assets (ROA) & Net income/Total assets & G2 & Positive/Negative \\
\hline
\end{tabular}

The choice of explanatory variables is driven by availability considerations and multicollinearity issues. Correlation analyses and collinearity diagnostics were performed to assess the extent of multicollinearity among independent variables. These problems were detected using the correlation matrix and the variance inflation factor (VIF). As a result, the initially considered CET1 ratio (C4) and RWA/TA ratio (G1) were finally excluded.

\subsection{Methodology}

The panel data regression technique is the most appropriate method when the sample comprises cross-sectional and time-series data. The main benefit of using panel data is that they overcome the unobservable, constant and heterogeneous characteristics of each bank in the sample [43]. In panel data models, the stochastic part $\left(\varepsilon_{i t}\right)$ consists of two components: $u_{i}$ and $e_{i t}$ The unobserved heterogeneity $\left(u_{i}\right)$ represents the bank-specific error term, capturing all the variation at the bank level that is not controlled for by the independent variables in the model. The idiosyncratic error $\left(e_{i t}\right)$ captures all peculiarities, apart from the effects that are already controlled for in the model, that affect the dependent variable for each bank at each point in time [44]. The Hausman test indicates in all cases that fixed effects models are preferred. These models assume that $u_{i}$ is correlated with the variables. Our baseline equation is the following:

$$
\begin{aligned}
\mathrm{PD}_{i t}=\alpha+ & \beta_{1} \times C 1_{i, t}+\beta_{2} \times C 3_{i, t}+\beta_{3} \times L 1_{i, t}+\beta_{4} \times L 2_{i, t} \\
& +\beta_{5} \times L 3_{i, t}+\beta_{6} \times A Q 1_{i, t}+\beta_{7} \times G 2_{i, t}+\varepsilon_{i, t}
\end{aligned}
$$


where $\mathrm{PD}_{i t}$ represents the probability of default of the bank $i$ in year $t$; the notations of the explanatory variables are described in Table 2; the subscripts $i$ and $t$ represent banks and years, respectively; $\alpha$ is the constant term; $\beta_{k}$ are the coefficient estimates; and $\varepsilon_{i t}$ is the disturbance.

\section{Results}

\subsection{Relationship between EBA Bank Risk Indicators and PD}

First, we report the results of the econometric models for the entire sample of credit institutions (Table 3). The Hausman test shows that the best model is a fixed effects (within) one. This model recognises the existence of individual differences at the level of banks (unobserved heterogeneity $u_{i}$ ) that are not controlled for by the explanatory variables so that the PD of each bank depends on individual factors that cannot be observed.

Table 3. Relationships between risk indicators and PD for Spanish banks.

\begin{tabular}{|c|c|c|c|}
\hline & (1) & (2) & (3) \\
\hline $\mathrm{C} 1$ & $\begin{array}{c}-0.01920^{* * *} \\
(0.00315)\end{array}$ & $\begin{array}{c}-0.01834^{* * *} \\
(0.00332)\end{array}$ & $\begin{array}{c}-0.01904^{* * *} \\
(0.00329)\end{array}$ \\
\hline $\mathrm{C} 3$ & $\begin{array}{c}-0.00049^{* * *} \\
(0.00006)\end{array}$ & $\begin{array}{c}-0.00050^{* * * *} \\
(0.00006)\end{array}$ & $\begin{array}{c}-0.00044^{* * *} \\
(0.00006)\end{array}$ \\
\hline L1 & $\begin{array}{c}-0.00026^{*} \\
(0.00013)\end{array}$ & $\begin{array}{c}-0.00024 * \\
(0.00013)\end{array}$ & $\begin{array}{l}-0.00021 \\
(0.00014)\end{array}$ \\
\hline $\mathrm{L} 2$ & $\begin{array}{l}-0.00029 \\
(0.00020)\end{array}$ & $\begin{array}{l}-0.00030 \\
(0.00020)\end{array}$ & $\begin{array}{l}-0.00017 \\
(0.00021)\end{array}$ \\
\hline L3 & $\begin{array}{c}-0.00081^{* *} \\
(0.00038)\end{array}$ & $\begin{array}{c}-0.00080^{* *} \\
(0.00038)\end{array}$ & $\begin{array}{c}-0.00086^{* *} \\
(0.00038)\end{array}$ \\
\hline AQ1 & $\begin{array}{c}-0.00713^{* * *} \\
(0.00113)\end{array}$ & $\begin{array}{c}-0.00732 * * * \\
(0.00116)\end{array}$ & $\begin{array}{c}-0.004199^{* * *} \\
(0.00149)\end{array}$ \\
\hline G2 & $\begin{array}{c}0.00423 \\
(0.00460)\end{array}$ & $\begin{array}{c}0.00456 \\
(0.00462)\end{array}$ & $\begin{array}{c}0.00196 \\
(0.00513)\end{array}$ \\
\hline Constant & $\begin{array}{c}0.52557^{* * * *} \\
(0.02951)\end{array}$ & $\begin{array}{c}0.40203^{* * * *} \\
(0.15251)\end{array}$ & $\begin{array}{c}0.48428 * * * \\
(0.03537)\end{array}$ \\
\hline Size & - & $\begin{array}{c}0.00737 \\
(0.00892)\end{array}$ & - \\
\hline Year dummies & - & - & Yes \\
\hline GDP & - & - & $\begin{array}{c}-0.00300 * \\
(0.00175)\end{array}$ \\
\hline Inflation & - & - & $\begin{array}{c}0.00916^{* * * *} \\
(0.00259)\end{array}$ \\
\hline Risk Premium & - & - & $\begin{array}{c}-0.00009^{* *} \\
(0.00004)\end{array}$ \\
\hline Number of obs. & 359 & 359 & 359 \\
\hline $\mathrm{F}(d f)$ & $45.50(7,282)$ & $39.85(8,281)$ & $23.00(15,274)$ \\
\hline Prob > F & 0.0000 & 0.0000 & 0.0000 \\
\hline$R^{2}$ (within) & 0.5304 & 0.5315 & 0.5573 \\
\hline Hausman & $27.01(7)$ & $29.16(8)$ & $29.42(12)$ \\
\hline
\end{tabular}

Notes: This table reports the results of the fixed effects (within) regressions for the entire sample (70 financial institutions). Model (1) includes only the main indicators. The Model (2) includes the variable size of the entity. Model (3) includes macroeconomic variables and time dummies. The standard errors are reported in parentheses. $R^{2}$ is the proportion of variation in the dependent variable explained by the model. The Hausman test compares the fixed versus random effects, asymptotically distributed as $\chi^{2}$ under the hypothesis that the individual effects are uncorrelated with the other regressors in the model, with degrees of freedom in parentheses. ${ }^{* * *}$, and ${ }^{* * *}$ indicate statistical significance at the $10 \%, 5 \%$ and $1 \%$ levels, respectively. 
The results of the baseline Model (1) show significant coefficients for the capital adequacy ratios, indicating the relevant impact of these variables on the banks' probability of default. The $\mathrm{C} 1$ and C3 ratios have significantly negative impacts on PD such that an increase in the capitalisation of banks increases the ability to absorb sudden losses and, therefore, to reduce the probability of default. Our findings support previous research, such as Čihák and Schaeck [45], Baselga-Pascual et al. [15] and Leung et al. [46].

Regarding the influence of liquidity indicators on bank risk, the literature has not produced conclusive findings. Ahmand and Arrif [11] found evidence for both a positive and a negative relationship between liquidity indicators and credit risk, depending on the analysed country. For some countries, the authors suggested that banks with more liquid assets tend to have higher credit risk. They believed that this contrasting result might be due to short-term assets or loans that banks own to hold more liquid assets to defend against rapidly changing interest rate markets. Corroborating this belief, Khan et al. [20] found that banks with lower fund liquidity risk tend to take more risks. In other countries, Ahmand and Arrif [11] found that liquidity is negatively related to credit risk. Veloz and Benou de Gomez [10] and Baselga-Pascual et al. [15] supported the premise that banks with higher levels of liquidity are less likely to experience an increase in the default rate. Our research also supports this last premise: the liquidity indicators (L1 and L3) appear to be statistically significant, such that the higher the liquidity is, the lower the probability of default of the commercial banks is.

The asset quality of banks also influences our measure of PD. There is a general consensus in the literature that an increase in the percentage of non-performing loans (NPLs) can reduce the quality of the banking sector's assets and increase the probability of default (e.g., [13,15,47-49]). However, following the financial crisis, higher capital requirements can generate the opposite effect, encouraging banks to increase risk taking, although this increase in risk taking is offset by the beneficial impact of increased loss absorbing arising from higher capital requirements, leading to more stable banks [18,50-52]. Our findings agree with this last argument. An increase in the delinquency rate is offset by a reinforcement of capital, and this higher buffer of capital will lead to lower unexpected losses and therefore lower PD. Finally, the remaining variable related to profitability does not prove to be significant.

In Model (2), we introduced the logarithm of the total assets as a proxy for the size of the bank, but it does not have any impact on PD. This result supports the "one-size-fits-all" financial regulation for the Spanish banking system.

In Model (3), we control for the macroeconomic variables and we find a relevant impact of GDP growth, inflation and risk premium on the probability of default of Spanish banks. These results indicate that the traditional bank risk indicators are not the only determinants of the new measure of PD from a regulatory approach. Therefore, the PD based on the SYMBOL model should be used jointly with the traditional indicators for a more complete analysis of the bank risk.

\subsection{Differences between Commercial Banks and Credit Cooperatives}

We contrast the existence of significant differences between groups of entities (commercial banks and credit cooperatives) using analysis of variance (ANOVA). Table 4 shows the descriptive statistics (mean and standard deviation) and the results for the Welch test (Because the majority of variables do not meet the assumption of homoscedasticity, we employ Welch's test, which is more robust if this assumption fails. Levene's test is employed to contrast the homogeneity of variances).

The results show notable differences in the risk profiles of commercial banks and credit cooperatives. There are significant differences in the level of solvency by type of entity. The mean probability of default for commercial banks is higher than the mean PD for credit cooperatives. Furthermore, credit cooperatives have higher mean values of capital adequacy (C1 and C3) and liquidity indicators (L1, L2, and L3). From this initial outline, we can deduce the existence of different risk profiles among Spanish banks. It seems that credit cooperatives have contributed to financial 
stability to a greater extent than commercial banks, perhaps because the cooperative business model of credit cooperatives in Spain is more conservative about taking risks.

Table 4. Summary statistics for commercial banks and credit cooperatives.

\begin{tabular}{|c|c|c|c|c|}
\hline & Commercial Banks & Cooperative Credit Unions & Total & Welch's Test \\
\hline PD & $\begin{array}{c}0.211 \\
(0.083)\end{array}$ & $\begin{array}{c}0.177 \\
(0.083)\end{array}$ & $\begin{array}{c}0.201 \\
(0.085)\end{array}$ & $12.805^{* * *}$ \\
\hline $\mathrm{C} 1$ & $\begin{array}{c}5.984 \\
(1.363)\end{array}$ & $\begin{array}{c}6.828 \\
(1.432)\end{array}$ & $\begin{array}{c}6.250 \\
(1.438)\end{array}$ & $27.698^{* * *}$ \\
\hline $\mathrm{C} 3$ & $\begin{array}{l}173.561 \\
(61.765)\end{array}$ & $\begin{array}{l}214.895 \\
(51.245)\end{array}$ & $\begin{array}{l}186.571 \\
(61.659)\end{array}$ & $44.094^{* * *}$ \\
\hline L1 & $\begin{array}{c}84.659 \\
(26.227)\end{array}$ & $\begin{array}{c}91.563 \\
(18.943)\end{array}$ & $\begin{array}{c}86.832 \\
(24.358)\end{array}$ & $7.983 * * *$ \\
\hline $\mathrm{L} 2$ & $\begin{array}{l}109.424 \\
(26.350)\end{array}$ & $\begin{array}{l}128.120 \\
(34.130)\end{array}$ & $\begin{array}{l}115.309 \\
(30.252)\end{array}$ & $26.620^{* * *}$ \\
\hline L3 & $\begin{array}{c}20.061 \\
(12.187)\end{array}$ & $\begin{array}{c}26.908 \\
(13.134)\end{array}$ & $\begin{array}{c}22.216 \\
(12.875)\end{array}$ & $22.010^{* * *}$ \\
\hline AQ1 & $\begin{array}{c}5.790 \\
(3.423) \\
\end{array}$ & $\begin{array}{c}5.784 \\
(3.854) \\
\end{array}$ & $\begin{array}{c}5.788 \\
(3.559) \\
\end{array}$ & 0.002 \\
\hline G2 & $\begin{array}{c}0.277 \\
(0.662)\end{array}$ & $\begin{array}{c}0.341 \\
(0.530)\end{array}$ & $\begin{array}{c}0.297 \\
(0.623)\end{array}$ & 0.963 \\
\hline
\end{tabular}

Notes: This table reports the means and standard deviations (in parentheses) for the commercial banks, the credit cooperatives and the entire sample during the period of 2008-2016. We also report the results of the test for differences in means to analyse the statistically significant differences. ${ }^{* * *}$ Significant at the $1 \%$ level.

The previous literature found some evidence concerning the influences of the ownership structure and the sizes of banks on their risk. Klomp and Haan [53] found that the effects of banking regulation and supervision on bank risk depends not only on the level of risk of the bank but also on its ownership structure and size as well. In this sense, Shehzad et al. [54] stated that risk-taking behaviour depends on the bank ownership concentration. Finally, Vázquez and Federico [55] concluded that smaller banks are more vulnerable to liquidity problems, while larger banking groups usually have a lack of capital buffers. Based on these findings, we introduce interaction dummies into our econometric models to explore the impact of the risk indicators on PD by type of entity (see Table 5).

The statistical significance of the interaction dummies in the specification (1) indicates that the effects of the risk indicators on the PD differ by type of entity. In fact, for commercial banks (2), the capital adequacy $(\mathrm{C} 1$ and $\mathrm{C} 3)$ and the asset quality (AQ1) ratios appear to be significant, whereas for credit cooperatives (3), the capital (C3) and the liquidity (L3) indicators seem to be the most important determinants of the PD. This result shows notable differences regarding key factors in the risk profiles of commercial banks and credit cooperatives, and our findings agree with research previously mentioned [53-55].

\subsection{Differences between Crisis and Post-Crisis Periods}

Finally, we contrasted the existence of significant differences between the crisis period (2008-2012) and the post-crisis period (2013-2016) using analysis of the Variance (ANOVA). We considered the post-crisis period from 2013, when the first signs of economic recovery were seen (some signs are the reduction in 10-year Germany bond spreads and the increases in real GDP and domestic demand) (Bank of Spain, 2017).

Table 6 shows the descriptive statistics (mean and standard deviation), and the results of the Welch test. 
The results show notable differences in the risk profiles of banks during and after the most recent financial crisis. The mean probability of default after the crisis is much lower than the mean PD for the crisis period. Furthermore, after the crisis, Spanish banks presented higher mean values of capital adequacy and liquidity indicators. Finally, the delinquency rate experienced an increase after the crisis. From this initial outline, we can deduce that Spanish banking institutions presented a better financial situation after the crisis, likely because of the regulatory actions adopted.

Table 5. Differences in the determinants of the probability of default by type of entity.

\begin{tabular}{|c|c|c|c|}
\hline & (1) Interaction Dummies & (2) Commercial Banks & (3) Credit Cooperatives \\
\hline $\mathrm{C} 1$ & $\begin{array}{l}-0.00567 \\
(0.00528)\end{array}$ & $\begin{array}{c}-0.02849^{* * *} \\
(0.00400)\end{array}$ & $\begin{array}{l}-0.00567 \\
(0.00528)\end{array}$ \\
\hline $\mathrm{C} 3$ & $\begin{array}{c}-0.00088^{* * *} \\
(0.00014)\end{array}$ & $\begin{array}{c}-0.00033^{* * *} \\
(0.00007)\end{array}$ & $\begin{array}{c}-0.00088^{* * *} \\
(0.00014)\end{array}$ \\
\hline L1 & $\begin{array}{l}-0.00042 \\
(0.00027)\end{array}$ & $\begin{array}{c}-0.00026^{*} \\
(0.00015)\end{array}$ & $\begin{array}{l}-0.00042 \\
(0.00027)\end{array}$ \\
\hline $\mathrm{L} 2$ & $\begin{array}{c}0.00034 \\
(0.00033)\end{array}$ & $\begin{array}{l}-0.00004 \\
(0.00029)\end{array}$ & $\begin{array}{c}0.00034 \\
(0.00033)\end{array}$ \\
\hline L3 & $\begin{array}{c}-0.00214^{* *} \\
(0.00086)\end{array}$ & $\begin{array}{l}-0.00060 \\
(0.00044)\end{array}$ & $\begin{array}{c}-0.00214^{* *} \\
(0.00086)\end{array}$ \\
\hline AQ1 & $\begin{array}{l}-0.00299 \\
(0.00193)\end{array}$ & $\begin{array}{c}-0.00959^{* * *} \\
(0.00139)\end{array}$ & $\begin{array}{l}-0.00299 \\
(0.00193)\end{array}$ \\
\hline G2 & $\begin{array}{l}-0.00417 \\
(0.00908)\end{array}$ & $\begin{array}{c}0.00475 \\
(0.00524)\end{array}$ & $\begin{array}{l}-0.00417 \\
(0.00908)\end{array}$ \\
\hline Constant & $\begin{array}{c}0.51424^{* * *} \\
(0.03094)\end{array}$ & $\begin{array}{c}0.51424^{* * *} \\
(0.03094)\end{array}$ & $\begin{array}{c}0.51424^{* * *} \\
(0.03094)\end{array}$ \\
\hline Number of obs. & 359 & 246 & 113 \\
\hline C1 x dummy type & $\begin{array}{c}-0.02282^{* * *} \\
(0.00662)\end{array}$ & & \\
\hline C3 $x$ dummy type & $\begin{array}{c}0.00055^{* * *} \\
(0.00016)\end{array}$ & & \\
\hline L1 x dummy type & $\begin{array}{c}0.00016 \\
(0.00031)\end{array}$ & & \\
\hline L2 $x$ dummy type & $\begin{array}{l}-0.00038 \\
(0.00044)\end{array}$ & & \\
\hline L3 x dummy type & $\begin{array}{c}0.00153 \\
(0.00096)\end{array}$ & & \\
\hline AQ1 x dummy type & $\begin{array}{c}-0.00660^{* * *} \\
(0.00238)\end{array}$ & & \\
\hline G2 x dummy type & $\begin{array}{c}0.00892 \\
(0.01049)\end{array}$ & & \\
\hline $\mathrm{F}(d f)$ & $26.56(14,275)$ & & \\
\hline Prob $>F$ & 0.0000 & & \\
\hline$R^{2}$ (within) & 0.5748 & & \\
\hline Hausman & $26.28(14)$ & & \\
\hline
\end{tabular}

Notes: This table reports the results of fixed effects (within) regressions. The model in Column (1) includes interaction dummies. Considering the differences in the determinants of PD by type of entity, we report the coefficients of the regression for commercial banks (2) and for credit cooperatives (3). The standard errors are reported in parentheses. $R^{2}$ is the proportion of variation in the dependent variable explained by the model. The Hausman test compares the fixed versus random effects, asymptotically distributed as $\chi^{2}$ under the hypothesis that the individual effects are uncorrelated with the other regressors in the model, with degrees of freedom in parentheses. ${ }^{*}, * *$ and ${ }^{* * *}$ indicate statistical significance at the $10 \%, 5 \%$ and $1 \%$ levels, respectively. 
Table 6. Summary statistics for periods of time.

\begin{tabular}{|c|c|c|c|c|}
\hline & 2008-2012 & 2013-2016 & Total & Welch's Test \\
\hline PD & $\begin{array}{c}0.226 \\
(0.084)\end{array}$ & $\begin{array}{c}0.156 \\
(0.065)\end{array}$ & $\begin{array}{c}0.201 \\
(0.085)\end{array}$ & $77.129^{* * *}$ \\
\hline $\mathrm{C} 1$ & $\begin{array}{c}6.320 \\
(1.436)\end{array}$ & $\begin{array}{c}6.127 \\
(1.437)\end{array}$ & $\begin{array}{c}6.250 \\
(1.438)\end{array}$ & 1.499 \\
\hline $\mathrm{C} 3$ & $\begin{array}{l}169.311 \\
(37.324) \\
\end{array}$ & $\begin{array}{l}216.976 \\
(81.414) \\
\end{array}$ & $\begin{array}{l}186.571 \\
(61.659) \\
\end{array}$ & $39.810^{* * *}$ \\
\hline L1 & $\begin{array}{c}84.732 \\
(22.267) \\
\end{array}$ & $\begin{array}{c}90.532 \\
(27.359) \\
\end{array}$ & $\begin{array}{c}86.832 \\
(24.358)\end{array}$ & $4.246^{* *}$ \\
\hline L2 & $\begin{array}{l}108.732 \\
(20.131)\end{array}$ & $\begin{array}{l}126.893 \\
(40.144)\end{array}$ & $\begin{array}{l}115.309 \\
(30.252)\end{array}$ & $23.282^{* * *}$ \\
\hline L3 & $\begin{array}{l}18.848 \\
(9.085)\end{array}$ & $\begin{array}{c}28.150 \\
(16.078)\end{array}$ & $\begin{array}{c}22.216 \\
(12.875)\end{array}$ & $36.839 * * *$ \\
\hline AQ1 & $\begin{array}{c}4.368 \\
(2.249) \\
\end{array}$ & $\begin{array}{c}8.289 \\
(4.040)\end{array}$ & $\begin{array}{c}5.788 \\
(3.559) \\
\end{array}$ & $104.145^{* * *}$ \\
\hline G2 & $\begin{array}{c}0.269 \\
(0.681)\end{array}$ & $\begin{array}{c}0.346 \\
(0.505)\end{array}$ & $\begin{array}{c}0.297 \\
(0.623)\end{array}$ & 1.483 \\
\hline
\end{tabular}

Following these arguments, we introduce interaction dummies into our econometric models to explore the impact of the risk indicators on PD by period of time (see Table 7).

Table 7. Differences in the determinants of the probability of default by periods of time.

\begin{tabular}{|c|c|c|c|}
\hline & Interaction Dummies & (1) Crisis Period & (2) Post-Crisis Period \\
\hline $\mathrm{C} 1$ & $\begin{array}{c}-0.01251^{* * *} \\
(0.00366)\end{array}$ & $\begin{array}{l}0.01267 * * \\
(0.00504)\end{array}$ & $\begin{array}{c}-0.01251^{* * *} \\
(0.00366)\end{array}$ \\
\hline $\mathrm{C} 3$ & $\begin{array}{c}-0.00032^{* * *} \\
(0.00006)\end{array}$ & $\begin{array}{c}-0.00211^{* * * *} \\
(0.00021)\end{array}$ & $\begin{array}{c}-0.00032 * * * \\
(0.00006)\end{array}$ \\
\hline L1 & $\begin{array}{c}0.00003 \\
(0.00014)\end{array}$ & $\begin{array}{c}-0.00065 * \\
(0.00036)\end{array}$ & $\begin{array}{c}0.00003 \\
(0.00014)\end{array}$ \\
\hline $\mathrm{L} 2$ & $\begin{array}{c}-0.00035^{*} \\
(0.00020)\end{array}$ & $\begin{array}{c}0.00034 \\
(0.00042)\end{array}$ & $\begin{array}{c}-0.00035^{*} \\
(0.00020)\end{array}$ \\
\hline L3 & $\begin{array}{c}-0.00076^{* *} \\
(0.00038)\end{array}$ & $\begin{array}{c}0.00004 \\
(0.00055)\end{array}$ & $\begin{array}{c}-0.00076^{* *} \\
(0.00038)\end{array}$ \\
\hline AQ1 & $\begin{array}{l}-0.00129 \\
(0.00149)\end{array}$ & $\begin{array}{l}-0.00037 \\
(0.00197)\end{array}$ & $\begin{array}{l}-0.00129 \\
(0.00149)\end{array}$ \\
\hline G2 & $\begin{array}{c}0.01204 \\
(0.00864)\end{array}$ & $\begin{array}{l}-0.00217 \\
(0.00534)\end{array}$ & $\begin{array}{c}0.01204 \\
(0.00864)\end{array}$ \\
\hline Constant & $\begin{array}{c}0.36656^{* * *} \\
(0.03891)\end{array}$ & $\begin{array}{c}0.52600 * * * \\
(0.03601)\end{array}$ & $\begin{array}{c}0.36656^{* * *} \\
(0.03891)\end{array}$ \\
\hline Dummy crisis & $\begin{array}{c}0.15944^{* * *} \\
(0.04199)\end{array}$ & & \\
\hline Number of obs. & 359 & 229 & 130 \\
\hline $\mathrm{C} 1 \mathrm{x}$ dummy crisis & $\begin{array}{c}0.02518^{* * *} \\
(0.00514)\end{array}$ & & \\
\hline $\mathrm{C} 3 \times$ dummv crisis & $-0.00179^{* * *}$ & & \\
\hline
\end{tabular}


Table 7. Cont.

\begin{tabular}{|c|c|c|}
\hline & Interaction Dummies & (2) Post-Crisis Period \\
\hline \multicolumn{3}{|c|}{$(0.00022)$} \\
\hline L1 $x$ dummy crisis & $\begin{array}{c}-0.00068 * \\
(0.00037)\end{array}$ & \\
\hline L2 $x$ dummy crisis & $\begin{array}{c}0.00069 \\
(0.00042)\end{array}$ & \\
\hline L3 $x$ dummy crisis & $\begin{array}{c}0.00081 \\
(0.00059)\end{array}$ & \\
\hline AQ1 $x$ dummy crisis & $\begin{array}{c}0.00092 \\
(0.00193)\end{array}$ & \\
\hline G2 $x$ dummy crisis & $\begin{array}{l}-0.01422 \\
(0.01018)\end{array}$ & \\
\hline $\mathrm{F}(d f)$ & $32.94(15,274)$ & \\
\hline Prob > F & 0.0000 & \\
\hline$R^{2}$ (within) & 0.6433 & \\
\hline Hausman & $76.08(15)$ & \\
\hline \multicolumn{3}{|c|}{$\begin{array}{l}\text { Notes: This table reports the results of fixed effects (within) regressions. The model in Column (1) includes } \\
\text { interaction dummies. Considering the differences in the determinants of PD by period of time, we report the } \\
\text { coefficients of the regression for the crisis period ( } 2 \text { ) and for the post-crisis period (3). The standard errors are } \\
\text { reported in parentheses. } R^{2} \text { is the proportion of variation in the dependent variable explained by the model. The } \\
\text { Hausman test compares the fixed versus random effects, asymptotically distributed as } \chi^{2} \text { under the hypothesis } \\
\text { that the individual effects are uncorrelated with the other regressors in the model, with degrees of freedom in } \\
\text { parentheses. }{ }^{*}, * * \text { and }{ }^{* * *} \text { indicate statistical significance at the } 10 \%, 5 \% \text { and } 1 \% \text { levels, respectively. }\end{array}$} \\
\hline
\end{tabular}

The statistical significance of the interaction dummies in specification (1) indicates that the effects of the risk indicators on the PD differ by period of time. In fact, during the crisis period (2), the main determinants of PD were the capital adequacy (C1 and C3) ratios, whereas after the financial crisis (3), the liquidity (L2 and L3) indicators seem to also be important determinants of the PD. Our findings agree with Vázquez and Federico [55], who concluded that banks with structural liquidity difficulties and higher leverage during a pre-crisis period are more prone to experience distress in a post-crisis period. These results show notable differences regarding key factors in the risk profiles of Spanish banks during and after the crisis.

\section{Conclusions}

Given the importance of stress exercises as an element of analysis and a policy tool, the EU started to use a new model, called SYMBOL, to measure the quantitative impact of different European Commission proposals. The model can also be used to determine the probability of bank default under the Basel regulatory approach [5]. Our work extends the previous research on the determinants of bank risk, analysing the relationships between the risk indicators proposed by the EBA [7] and the individual default probabilities of Spanish credit institutions during the period of 2008-2016, based on a new measure supported by banking regulation.

Our results for Spanish banking credit institutions reveal that capital adequacy, liquidity and asset quality are the main determinants of the banks' probability of default from a regulatory approach. The macroeconomic scenario appears to be significant as well. In addition, the explanatory power of the models indicates that the traditionally used indicators are not the only determinants of the new measure of banks' PD. Thus, this new proxy could be supplementary to the traditional risk indicators in bank risk analysis.

When we contrast the existence of significant differences between groups of entities, we find different risk profiles between commercial banks and credit cooperatives. The mean probability of 
default of commercial banks is higher than the mean PD of credit cooperatives. Furthermore, the credit cooperatives present greater capital adequacy and liquidity than commercial banks. It seems that Spanish credit cooperatives have contributed to financial stability to a greater extent than commercial banks. In addition, the introduction of interaction dummies into the models reveals that the influence of each indicator in the PD differs by the type of entity. For commercial banks, the probability of default is mainly influenced by the capital adequacy (C1 and C3) and asset quality (AQ1) ratios, while, for credit cooperatives, the capital (C3) and liquidity (L3) indicators seem to be the most important determinants of the PD. These findings support previous research [53-55], and they reveal notable differences regarding the key factors in the risk management of commercial banks and credit cooperatives.

Regarding the influence of the most recent financial crisis, we can deduce that Spanish banking institutions present a better financial situation after the crisis, likely because of the regulatory actions adopted. The results show that the mean probability of default after the crisis is much lower than the mean PD for the crisis period. Furthermore, after the crisis, Spanish banks present higher mean values of capital adequacy and liquidity indicators. The statistical significance of the interaction dummies indicates that the effects of the risk indicators on the PD also differ by period of time. In fact, during the crisis period, the main determinants of PD were the capital adequacy (C1 and C3) ratios, whereas after the financial crisis, the liquidity (L2 and L3) indicators also seem to be important determinants of the PD. Our findings agree with Vázquez and Federico [55].

In conclusion, our findings could be important to regulatory and supervisory authorities for several reasons. First, the PD based on the SYMBOL model could be considered to analyse bank risk from a regulatory approach. It could be used jointly with the traditional indicators for a more complete analysis of unexpected bank losses. Second, given the standardised calculation of this measurement, it could enable comparisons across different credit institutions [56], thus improving market discipline. Finally, our results might be useful to the design of new regulations focused on the key factors that affect the banks' probability of default. We have shown the importance of considering the differences between types of entities from the point of view of financial stability, indicating that the emphasis of regulation and supervision in Spain should differ by type of entity to control for different risk factors.

Acknowledgments: We are grateful to the participants of the II Workshop of the ACEDE's Financial Economics Section (2017), the ACEDE 2017 XXVII Conference and the 23rd EBES Conference. Special thanks are due to the anonymous referees and the editor for their guidance and very constructive comments. Finally, we also acknowledge the financial support of the University of Cantabria Foundation for Education and Research in the Financial Sector (UCEIF) and the Santander Financial Institute (SANFI) (2016 Research Grant). The usual disclaimer applies.

Author Contributions: All the authors have contributed equally to the paper.

Conflicts of Interest: The authors declare no conflict of interest.

\section{References}

1. Basel Committee on Banking Supervision. Basel III: International Regulatory Framework for Banks; Basel Committee on Banking Supervision: New York, NY, USA, 2011.

2. European Commission. Directorate-General for Economic and Financial Affairs. Fiscal Sustainability Report. 2012. Available online: http:/ / ec.europa.eu/economy_finance/publications/european_economy/2012/ pdf/ee-2012-8_en.pdf (accessed on 12 August 2016).

3. European Commission. Effects Analysis (EA) on the European Deposit Insurance Scheme (EDIS). 2016. Available online: https:/ / ec.europa.eu/info/publications/effects-analysis-european-deposit-insurancescheme-edis_en (accessed on 27 September 2017).

4. De Lisa, R.; Zedda, S.; Vallascas, F.; Campolongo, F.; Marchesi, M. Modelling deposit insurance scheme losses in a Basel 2 framework. J. Financ. Serv. Res. 2011, 40, 123-141. [CrossRef]

5. Repullo, R.; Suarez, J. Loan pricing under Basel capital requirements. J. Financ. Intermed. 2004, 13, 496-521. [CrossRef] 
6. Basel Committee on Banking Supervision. International Convergence of Capital Measurement and Capital Standards. A Revised Framework. 2004. Available online: https:/ / www.bis.org/publ/bcbs107.pdf (accessed on 10 July 2016).

7. European Banking Authority (EBA). Guidelines on Methods for Calculating Contributions to Deposit Guarantee Schemes; EBA/GL/2015/10. 2015. Available online: https:/ /www.eba.europa.eu/documents / 10180/1089322/EBA-GL-2015-10+GL+on+methods+for+calculating+contributions+to+DGS.pdf (accessed on 1 August 2016).

8. Berger, A.N.; DeYoung, R. Problem loans and cost efficiency in commercial banks. J. Bank. Financ. 1997, 21, 849-870. [CrossRef]

9. Salas, V.; Saurina, J. Credit Risk in Two Institutional Regimes: Spanish Commercial and Savings Banks. J. Financ. Serv. Res. 2002, 22, 203-224. [CrossRef]

10. Veloz, A.; Benou de Gómez, G. Determinantes de fragilidad del sistema bancario en la República Dominicana: Una aplicación micro-macro de modelos de alerta temprana. Sci. Soc. 2007, 32, 69-87. [CrossRef]

11. Ahmad, N.H.; Arrif, M. Multi-country study of bank credit risk determinants. Int. J. Bank. Financ. 2007, 5, 135-152.

12. Delis, M.D.; Kouretas, G.P. Interest rates and bank risk-taking. J. Bank. Financ. 2011, 35, 840-855. [CrossRef]

13. Festic, M.; Kavkler, A.; Repina, S. The macroeconomic sources of systemic risk in the banking sectors of five new EU member states. J. Bank. Financ. 2011, 35, 310-322. [CrossRef]

14. Climent-Serrano, S.; Pavía, J.M. An analysis of loan default determinants: the Spanish case. Banks Bank Syst. 2014, 9, 116-123.

15. Baselga-Pascual, L.; Trujillo-Ponce, A.; Cardone-Riportella, C. Factors influencing bank risk in Europe: Evidence from the financial crisis. N. Am. J. Econ. Financ. 2015, 34, 138-166. [CrossRef]

16. Agoraki, M.-E.K.; Delis, M.D.; Pasiouras, F. Regulations, competition and bank risk-taking in transition countries. J. Financ. Stab. 2011, 7, 38-48. [CrossRef]

17. Demirgüç-Kunt, A.; Huizinga, H. Bank activity and funding strategies: The impact on risk and returns. J. Financ. Econ. 2010, 98, 626-650. [CrossRef]

18. Laeven, L.; Levine, R. Bank governance, regulation and risk taking. J. Financ. Econ. 2009, 93, $259-275$. [CrossRef]

19. Lepetit, L.; Strobel, F. Bank insolvency risk and Z-score measures: A refinement. Financ. Res. Lett. 2015, 13, 214-224. [CrossRef]

20. Khan, M.S.; Scheule, H.; Wu, E. Funding liquidity and bank risk taking. J. Bank. Financ. 2017, 82, $203-216$. [CrossRef]

21. Delis, M.D.; Staikouras, P.K. Supervisory effectiveness and bank risk. Rev. Financ. 2011, 15, 511-543. [CrossRef]

22. Merton, R.C. On the pricing of corporate debt: The risk structure of interest rates. J. Financ. 1974, 29, 449-470.

23. Kool, C.J.M. Financial Stability in European Banking: The Role of Common Factors. Open Econ. Rev. 2006, 17, 525-540. [CrossRef]

24. Huang, X.; Zhou, H.; Zhu, H. A Framework for Assessing the Systemic Risk of Major Financial Institutions. Available online: https:/ / www.federalreserve.gov/pubs/feds/2009/200937/200937pap.pdf (accessed on 9 April 2018).

25. Hart, O.; Zingales, L. A New Capital Regulation for Large Financial Institutions; CEPR Discussion Paper No. DP7298; NBER \& CEPR; University of Chicago: Chicago, IL, USA, 2009.

26. Alter, A.; Schüler, Y.S. Credit spread interdependencies of European states and banks during the financial crisis. J. Bank. Financ. 2012, 36, 3444-3468. [CrossRef]

27. Chiaramonte, L.; Casu, B. The determinants of bank CDS spreads: evidence from the financial crisis. Eur. J. Financ. 2013, 19, 861-887. [CrossRef]

28. Annaert, J.; De Ceuster, M.; Van Roy, P.; Vespro, C. What determines Euro area bank CDS spreads? J. Int. Money Finan. 2013, 32, 444-461. [CrossRef]

29. Hasan, I.; Liu, L.; Zhang, G. The Determinants of Global Bank Credit-Default-Swap Spreads. Available online: https:/ /link.springer.com/article/10.1007/s10693-015-0232-z (accessed on 9 April 2018).

30. Samaniego-Medina, R.; Trujillo-Ponce, A.; Parrado-Martínez, P.; di Pietro, F. Determinants of bank CDS spreads in Europe. J. Econ. Bus. 2016, 86, 1-15. [CrossRef] 
31. Drago, D.; Di Tommaso, C.; Thornton, J. What determines bank CDS spreads? Evidence from European and US banks. Financ. Res. Lett. 2017, 22, 140-145. [CrossRef]

32. Calomiris, C. Financial innovation, regulation and reform. Cato J. 2009, 29, 65-91.

33. Hau, H.; Langfield, S.; Marques-Ibanez, D. Bank Ratings. What Determines Their Quality? Working Paper Series, No. 1484; European Central Bank: Frankfurt, Germany, 2012.

34. Wang, L. Bank Rating Gaps as Proxies for Systemic Risk. University of Alberta, 2017. Available online: papers.ssrn.com/sol3/papers.cfm?abstract_id=2966413 (accessed on 9 April 2018).

35. Marchesi, M.; Petracco Giudici, M.; Cariboni, J.; Zedda, S.; Campolongo, F. Macroeconomic Cost-benefit Analysis of Basel III Minimum Capital Requirements and of Introducing Deposit Guarantee Schemes and Resolution Funds; European Commission JRC Scientific and Policy Report, 24603; EUR: Brussels, Belgium, 2012.

36. Cannas, G.; Cariboni, J.; Forys, M.; Joensson, H.; Langedijk, S.; Marchesi, M.; Nda-cyayisenga, N.; Pagano, A.; Petracco-Giudici, M. Quantitative Estimation of a Part of the Costs and Benefits of Bank Structural Separation; JRC Scientific and Technical Report; EUR: Brussels, Belgium, 2013.

37. Benczur, P.; Berti, K.; Cariboni, J.; Di Girolamo, F.E.; Langedijk, S.; Pagano, A.; Petracco Giudici, M. Banking Stress Scenarios for Public Debt Projections; European Economy Economic Papers; Economic Papers 548; Publications Office of the European Union: Luxembourg, 2015.

38. Benczur, P.; Cannas, G.; Cariboni, J.; Di Girolamo, F.; Maccaferri, S.; Petracco Giudici, M. Evaluating the effectiveness of the new EU bank regulatory framework: A farewell to bail-out? J. Financ. Stab. 2016, 33, 207-223. [CrossRef]

39. Gómez, P.; Partal, A.; Trujillo, A. A note on the adequacy of the EU scheme for bank recovery, resolution and deposit insurance in Spain. J. Bank Regul. 2016, 17, 332-337. [CrossRef]

40. Basel Committee on Banking Supervision. International Convergence of Capital Measurement and Capital Standards. A Revised Framework. 2006. Available online: https://www.bis.org/publ/bcbs128.pdf (accessed on 10 August 2016).

41. Cariboni, J.; Fontana, A.; Langedijk, S.; Maccaferri, S.; Pagano, A.; Petracco-Giudici, M.; Rancan, M.; Schich, S. Reducing and sharing the burden of bank failures. OECD J. Financ. Mark. Trends 2015, 2, 29-61. [CrossRef]

42. Muresano, R.; Pagano, A. Adapting and Optimizing the Systemic Model of Banking Originated Losses (SYMBOL) Tool to the Multi-core Architecture. Comput. Econ. 2016, 48, 253-280. [CrossRef]

43. Saona, P. Determinants of the Profitability of the US Banking Industry. Int. J. Bus. Soc. Sci. 2011, 2, $255-269$.

44. Andreß, H.-J.; Golsch, K.; Schmidt, A.W. Applied Panel Data Analysis for Economic and Social Surveys; Springer: Berlin/Heidelberg, Germany, 2013.

45. Čihák, M.; Schaeck, K. How Well Do Aggregate Prudential Ratios Identify Banking System Problems? J. Financ. Stab. 2010, 6, 130-144. [CrossRef]

46. Leung, W.S.; Taylor, N.; Evans, K.P. The determinants of bank risks: Evidence from the recent financial crisis. J. Int. Financ. Mark. Inst. 2015, 34, 277-293. [CrossRef]

47. De Nicoló, G.; Geadah, S.; Rozhkov, D. Bridging the great divide: Poorly developed financial systems in the CIS-7countries may jeopardize their sustained growth. Financ. Dev. 2003, 40, 42-45.

48. Blasco, M.; Sinkey, J. Bank asset structure, real-estate lending, and risk-taking. Q. Rev. Econ. Financ. 2006, 46, 53-81. [CrossRef]

49. Männasoo, K.; Mayes, D.G. Explaining bank distress in Eastern European transition economies. J. Bank. Financ. 2009, 33, 244-253. [CrossRef]

50. Jokipii, T.; Milne, A. Bank capital buffer and risk adjustment decisions. J. Financ. Stab. 2011, 7, $165-178$. [CrossRef]

51. Ghosh, A. Banking-industry specific and regional economic determinants of non-performing loans: Evidence from US states. J. Financ. Stab. 2015, 20, 93-104. [CrossRef]

52. Acosta, J.; Grill, M.; Hannes, J. The Leverage Ratio, Risk-Taking and Bank Stability; Working Paper Series, No. 2079; European Central Bank: Frankfurt, Germany, 2017.

53. Klomp, J.; Haan, J. Banking risk and regulation: Does one size fit all? J. Bank. Financ. 2012, 36, 3197-3212. [CrossRef]

54. Shehzad, C.T.; Haan, J.; Scholtens, B. The impact of bank ownership concentration on impaired loans and capital adequacy. J. Bank. Financ. 2010, 34, 399-408. [CrossRef] 
55. Vazquez, F.; Federico, P. Bank funding structures and risk: Evidence from the global financial crisis. J. Bank. Financ. 2015, 61, 1-14. [CrossRef]

56. Schmieder, C.; Schumacher, L. Introduction to the balance sheet-based approach to stress testing. In A Guide to IMF Stress Testing: Methods and Models; Ong, L.L., Ed.; International Monetary Fund: Washington, DC, USA, 2014; pp. 13-16. 